\title{
IMMUNOCYTOCHEMICAL LOCALIZATION OF THE MAMMALIAN VOLTAGE-DEPENDENT SODIUM CHANNEL USING POLYCLONAL ANTIBODIES AGAINST THE PURIFIED PROTEIN ${ }^{1}$
}

\author{
BEATRICE HAIMOVICH, ${ }^{*}$ EDUARDO BONILLA, ${ }^{*, 2}$ JAN CASADEI, ${ }^{*}$ AND ROBERT BARCHI ${ }^{*}{ }^{3}$ \\ ${ }^{*}$ Department of Neurology and $\ddagger$ the Institute for Neurological Sciences, University of Pennsylvania School of Medicine, \\ Philadelphia, Pennsylvania 19104
}

Received December 9, 1983; Accepted March 30, 1984

\begin{abstract}
Antibodies were raised in rabbits against the purified voltage-dependent sodium channel from rat skeletal muscle sarcolemma. The resultant antiserum reacted with the purified channel in a solid-phase radioimmunoassay and precipitated the sodium channel from a crude mixture of solubilized membrane proteins. Crude membrane proteins separated according to size under nondenaturing conditions by chromatography on Sepharose CL-6B contained a single peak of immunoreactivity that coincided with the native channel. On immunoblots of sarcolemmal membrane proteins, the antiserum reacted predominantly with a diffuse high molecular weight band that was comparable in migratory characteristics to the large glycoprotein subunit of the purified channel.

Using immunocytochemical techniques, binding of this polyclonal antiserum was localized to the surface membrane of rat skeletal muscle. This staining was specifically blocked by pre-incubation of the antiserum with the purified channel protein. The antiserum also stained the surface membrane of rat cardiac muscle and the nodes of Ranvier in rat peripheral nerve. Species cross-reactivity was seen with mouse, human, and guinea pig skeletal muscle while chicken, rabbit, and frog muscle was not stained. The antiserum also reacted with the surface membranes of fetal rat muscle in tissue culture.

These results indicate that sodium channels in adult mammalian skeletal muscle, cardiac muscle, and peripheral nerve and in fetal muscle in culture all share common antigenic determinants. The antiserum should prove useful for topographical studies of sodium channel distribution in these tissues.
\end{abstract}

The membrane action potential that characterizes electrically excitable cells, such as mammalian nerve and muscle, is the result of transient sequential increases in membrane conductance to sodium and potassium ions (Hodgkin and Huxley, 1952). These time- and voltage-dependent ionic conductances are controlled by separate intrinsic membrane proteins or channels (Armstrong, 1975). During the past few years, the voltagedependent sodium channel has been solubilized and purified from eel electroplax (Agnew et al., 1978) and from mammalian muscle (Barchi et al., 1980) and nerve (Hartshorne and Catterall, 1981), and many of its biochemical properties have been studied. However, information about the topographical distribution of sodium channels in excitable cells has been more difficult to obtain. Inferences concerning its distribution have been drawn largely from electrophysiological studies or from

\footnotetext{
${ }^{1}$ This work was supported in part by a grant from the Muscular Dystrophy Association and by National Institutes of Health Grants NS-08075 and NS-18013. We wish to acknowledge the assistance of Dr. Robert Gordon with some aspects of the work reported and the advice of Dr. Lois Lampson during the initial stages of antibody characterization.

${ }^{2}$ Present address: Department of Neurology, Columbia College of Physicians and Surgeons, New York, NY 10032.

${ }^{3}$ To whom correspondence should be addressed.
}

equilibrium measurements of radiolabeled toxin binding (Ritchie and Rogart, 1977a).

Ideally, studies of the localization and distribution of a membrane protein require a specific irreversible label that can be visualized easily with the morphological techniques being employed. Localization of sodium channels at the light and electron microscopy levels has been hampered by the lack of a label that will identify only this channel protein and yet remain associated with the protein during tissue processing. Most natural neurotoxins bind reversibly (Ritchie and Rogart, 1977a) or dissociate rapidly with depolarization (Catterall, 1980). The use of covalently incorporated toxins for histochemical localization has also proven difficult.

Antibodies raised against purified proteins can provide specific labels for immunohistochemical studies. Polyclonal antibodies prepared against the sodium channel from eel electroplax have been used to localize the channel in that preparation (Ellisman and Levinson, 1982) but do not appear to cross-react with mammalian excitable membranes. The availability of purified rat sodium channel protein provided us with the opportunity to generate similar antibodies against the mammalian channel.

We report here the characterization of a rabbit polyclonal antiserum raised against the purified voltage-dependent sodium channel from rat sarcolemma. This antiserum localizes the 
sodium channel in rat peripheral nerve as well as rat muscle and cross-reacts with the sodium channel in other mammalian muscle; it should provide a useful probe for sodium channel localization in mammalian nerve and muscle.

\section{Materials and Methods}

Purification of the sodium channel protein. The sarcolemmal sodium channel was purified from rat skeletal muscle sarcolemmal membranes as previously described (Barchi, 1983). Briefly, isolated sarcolemmal membranes were solubilized in $1 \%$ NP-40 at $2 \mathrm{mg} / \mathrm{ml}$ in $100 \mathrm{~mm}$ choline chloride, $50 \mathrm{mM} \mathrm{KP}$, and $0.5 \mathrm{mM} \mathrm{CaCl}_{2}$. This and all subsequent solutions contained the protease inhibitors leupeptin $(1 \mu \mathrm{g} / \mathrm{ml})$, PMSF $(0.1 \mathrm{mM})$, pepstatin $(0.1 \mu \mathrm{g} / \mathrm{ml}), O$-phenanthroline $(1 \mathrm{mM})$, and iodoacetamide (1 $\mathrm{mM})$. The solubilized sodium channel was subsequently purified by sequential chromatography on a guanidinium-Sepharose ion exchange column and an immobilized wheat germ agglutininSepharose affinity column. The peak of sodium channel protein that eluted from the wheat germ agglutinin-Sepharose column with $50 \mathrm{~mm}$ $N$-acetylglucosamine was used for most immunizations. This peak typically demonstrated 1000 to $2000 \mathrm{pmol}$ of specific saxitoxin binding/ $\mathrm{mg}$ of protein. For competition experiments a third step of purification on a 5 to $15 \%$ sucrose gradient was used to obtain sodium channel protein of higher specific activity $(\sim 2500 \mathrm{pmol}$ of saxitoxin $/ \mathrm{mg}$ of protein) (Barchi, 1983). Fractions used for immunization were dialyzed against PBS prior to use. Sodium channel activity was quantitated by specific binding of $\left[{ }^{3} \mathrm{H}\right]$ saxitoxin as previously described (Weigele and Barchi, 1978, Barchi et al., 1980).

Generation of rabbit antiserum. White New Zealand rabbits were immunized intradermally at multiple sites along the spine with 10 to $20 \mu \mathrm{g}$ of sodium channel protein emulsified 1:1 in Freund's complete adjuvant. A second injection of a similar quantity emulsified 1:1 in Freund's incomplete adjuvant was given 1 month later. Rabbits were bled 14 days subsequent to the second boost, and the serum was tested for antisodium channel antibodies as described below. In subsequent months the animal exhibiting the highest antibody titer was boosted periodically with an additional $10 \mu \mathrm{g}$ of sodium channel emulsified $1: 1$ in Freund's incomplete adjuvant and administered intraperitoneally. In each case serum was harvested 14 days after the intraperitoneal injection.

For some studies, serum was absorbed against rat liver powder (Cappel Laboratories). Serum was mixed 1:1 (v/v) with a suspension of liver powder $(100 \mathrm{mg} / \mathrm{ml})$ in PBS and incubated for $12 \mathrm{hr}$ at $4^{\circ} \mathrm{C}$ with gentle tumbling. The mixture was centrifuged at $100,000 \times \mathrm{g}$ for $30 \mathrm{~min}$. The supernatant was collected and filtered through a $0.45-\mu \mathrm{m}$ pore size HA Millipore filter. The filtrate will subsequently be referred to as preabsorbed antiserum.

Assay for antisodium channel antibodies. Serum was evaluated for antisodium channel antibody activity in a solid-phase radioimmunoassay. Multiwell microtiter plates were precoated for $30 \mathrm{~min}$ at room temperature with $0.25 \mu \mathrm{g}$ of poly-L-lysine (Sigma) in $25 \mu \mathrm{l}$ of PBS/well and were subsequently incubated overnight at $4^{\circ} \mathrm{C}$ with $10 \mu \mathrm{l}$ of PBS containing about $0.03 \mu \mathrm{g}$ of sodium channel protein/well. Purified protein of approximately 1000 to $1500 \mathrm{pmol}$ of saxitoxin binding/mg of protein was routinely used for screening.

After overnight incubation, the plates were washed three times with PBS and then treated for $30 \mathrm{~min}$ at $22^{\circ} \mathrm{C}$ with $25 \mu \mathrm{l}$ of PBS containing $10 \%$ horse serum, followed by a 2 -hr incubation at $22^{\circ} \mathrm{C}$ with the rabbit serum being evaluated diluted appropriately in the same buffer. After washing, the wells were incubated for a final $2 \mathrm{hr}$ with ${ }^{125} \mathrm{I}$-labeled goat anti-rabbit $\operatorname{IgG}\left(15,000\right.$ to $20,000 \mathrm{cpm} /$ well). Occasionally, [ $\left.{ }^{125} \mathrm{I}\right]$ protein A was used in place of goat anti-rabbit IgG with comparable results. The wells were rinsed, dried, removed from the plate using a hot wire, and counted in a gamma counter. The labeled goat IgG was provided by Dr. Michael Cancro (Department of Pathology, University of Pennsylvania).

Immunoprecipitation of the sodium channel. Staphylococcus aureus cells (Staph-A, Calbiochem) were washed according to the procedure described by Kessler (1976) and suspended $10 \%(\mathrm{v} / \mathrm{v})$ in PBS. One hundred-microliter aliquots of this suspension were pelleted in plastic Eppendorf tubes; the pellets were resuspended in $300 \mu$ l of PBS containing appropriate dilutions of control or immune serum and were incubated at $4^{\circ} \mathrm{C}$ for $12 \mathrm{hr}$ with gentle tumbling. The coated Staph A samples were collected by low speed centrifugation and washed in a buffer containing $100 \mathrm{mM}$ choline chloride, $50 \mathrm{mM} \mathrm{KP}$ ( $\mathrm{pH} 7.4), 0.5$ $\mathrm{mM} \mathrm{MgCl}_{2}, 0.5 \mathrm{mM} \mathrm{CaCl}$, and $0.05 \%$ NP-40 (buffer A). Rat skeletal muscle sarcolemma was solubilized in $1 \%$ NP-40, $100 \mathrm{mM}$ choline chloride, $50 \mathrm{mM} \mathrm{KP}$ ( $\mathrm{pH} 7.4$ ), and $0.5 \mathrm{mM} \mathrm{CaCl}_{2}$. The washed pellets of Staph A protein were each resuspended in $1 \mathrm{ml}$ of solubilized sarcolemma diluted to 0.4 to $0.8 \mathrm{mg} / \mathrm{ml}$ in buffer A. Samples were incubated overnight at $4^{\circ} \mathrm{C}$. Tritiated saxitoxin (specific activity 6.4 $\mathrm{Ci} / \mathrm{mmol}$ ) was then added to a final concentration of $15 \mathrm{~nm}$ with or without $1 \mu \mathrm{M}$ unlabeled tetrodotoxin for determination of specific saxitoxin binding activity. Toxin associated with channel protein bound to Staph A was separated from free by rapid filtration of triplicate 175$\mu \mathrm{l}$ aliquots from each sample on Whatman GF/F filters prewetted with buffer A. Filters were immediately washed with two 5-ml aliquots of buffer $A$. The complete filtration process was carried out in less than $15 \mathrm{sec}$ for each sample. Filters were subsequently counted in $5 \mathrm{ml}$ of ACS II scintillation fluid. Specific saxitoxin binding activity was expressed as total activity $\left(\left[{ }^{3} \mathrm{H}\right]\right.$ saxitoxin) minus nonspecific binding ( $\left[{ }^{3} \mathrm{H}\right]$ saxitoxin in the presence of $1 \mu \mathrm{M}$ tetrodotoxin).

Immunoblots. Rat skeletal muscle sarcolemma was solubilized in $2 \%$ SDS, $1.2 \%$ dithioerythritol, $20 \mathrm{mM}$ Tris (pH 6.8), $2 \mathrm{mM}$ EDTA, and proteins separated by SDS-PAGE using $12 \%$ acrylamide $/ 0.075 \%$ bisacrylamide gels after the method of Laemmli (1970). The bis-acrylamide concentration was lowered to facilitate subsequent transfer of high molecular weight proteins. Separated proteins were electrophoretically transferred to nitrocellulose paper in a buffer containing 190 $\mathrm{mm}$ glycinc, $20 \mathrm{~mm}$ Tris ( $\mathrm{pH} 8.3$ ), $30 \%$ methanol, and $0.1 \%$ SDS (Towbin et al., 1979). Strips of the transfer were first incubated with $3 \% \mathrm{BSA}$ in PBS for $12 \mathrm{hr}$ at $4^{\circ} \mathrm{C}$, then exposed to appropriate dilutions of antiserum or control serum in BSA-PBS for an additional $12 \mathrm{hr}$ at the same temperature. After exhaustive washing in PBS, strips were exposed to $\left.{ }^{125} \mathrm{I}\right]$ goat anti-rabbit IgG for $2 \mathrm{hr}$ at $20^{\circ} \mathrm{C}$ with agitation. Following further washing in PBS, strips were placed on Kodak XAR film for imaging.

Sepharose chromatography of sarcolemmal proteins. Sarcolemma was solubilized in $1 \% \mathrm{NP}-40$ as above, and $1.3 \mathrm{mg}$ of solubilized protein (11.6 pmol of $\left[{ }^{3} \mathrm{H}\right]$ saxitoxin binding/mg of protein) were applied to a $1.0 \times 95 \mathrm{~cm}$ column of Sepharose CL-6B. Elution was carried out in $100 \mathrm{mM}$ choline chloride, $50 \mathrm{mM} \mathrm{KP}$ ( $\mathrm{MgCl}_{2}$, and $0.1 \%$ NP-40/phosphatidyl choline (5:1 molar ratio). Column flow rate was $4.3 \mathrm{ml} / \mathrm{hr}$, and $0.96-\mathrm{ml}$ fractions were collected. Protein values were determined using a microadaption of the Lowry method (Markwell et al., 1981).

Immunocytochemistry. Frozen sections $(-10 \mu \mathrm{m})$ were prepared from fresh tissue samples and transferred to gelatin-coated coverslips. For immunoperoxidase studies, the sections were incubated for $2 \mathrm{hr}$ at room temperature with either polyclonal antibody or control serum diluted between 1:50 and 1:200 in PBS and then washed with three changes of PBS alone. Subsequently, the sections were incubated for $1 \mathrm{hr}$ at room temperature with protein A-peroxidase (PolyScience Inc.) diluted 1:30 or 1:50 in PBS and then again washed with three changes of PBS. The immunoperoxidase staining was developed for $10 \mathrm{~min}$ by reacting the tissue sections in a solution of $0.0038 \% 3,3$-diaminobenzidine (E.M. Science, Fort Washington, PA) and $0.05 \% \mathrm{H}_{2} \mathrm{O}_{2}$ in $0.2 \mathrm{M}$ Tris buffer (pH 7.4). The sections were finally washed in distilled water and mounted with glycerol-gel (Weir et al., 1974; Dubois-Dalcq, et al., 1977).

Nerve sections were treated as above except that they were fixed with $3 \%$ glutaraldehyde in $100 \mathrm{~mm}$ potassium phosphate after the protein A-peroxidase incubation. As a final step the sections were briefly exposed to $\mathrm{O}_{\mathrm{S}} \mathrm{O}_{4}(5 \mathrm{~min})$ and dehydrated in alcohol and xylene prior to mounting.

For competition studies with purified sodium channel, hyperimmune serum and control serum were diluted 1:750 in PBS. Aliquots of diluted serum were incubated overnight with increasing concentrations of purified sodium channel protein $\left(\sim 2500 \mathrm{pmol}\right.$ of $\left[{ }^{3} \mathrm{H}\right]$ saxitoxin $/ \mathrm{mg}$ of protein). Muscle frozen sections were exposed to these serum samples and then incubated for $30 \mathrm{~min}$ with a 1:500 dilution of rhodamineconjugated goat anti-rabbit IgG (Cappel Laboratories) preabsorbed against rat'liver powder. The sections were washed in PBS, mounted, and examined with a Zeiss II photomicroscope equipped with epifluorescence optics.

\section{Results}

Serum from rabbits immunized with the purified rat sodium channel protein will be designated SCP antiserum in this discussion. Serum was assayed for anti-sodium channel activity using a solid-phase assay. Wells of multititer plates were coated 
with purified sodium channel protein as described under "Materials and Methods." Increasing dilutions of immune serum were assayed using normal rabbit serum as control (Fig. 1). SCP antiserum demonstrated specific binding to sodium channel protein that peaked at dilutions between $1: 100$ and 1:1000. Specific immunoreactivity could be detected at dilutions in excess of $1: 10^{5}$. A small amount of binding over background was also seen to the detergent/lipid mixture used to stabilize the sodium channel during purification (NP-40/asolectin, 5:1 molar ratio). This increased background (see Fig. 1) was not blocked by pre-incubation of the serum with NP-40/asolectin or with vesicles formed from the asolectin lipids. Preabsorption of the serum with rat liver powder also had no effect.

Immunoprecipitation. SCP antiserum was capable of specifically precipitating the sodium channel, as identified by its specific saxitoxin binding activity, from a mixture of crude solubilized sarcolemmal membrane proteins. For immunoprecipitation, a preparation of Staph A was coated with control or hyperimmune serum and subsequently incubated with solubilized sarcolemmal membrane proteins. Sodium channel bound to the Staph A was quantitated by determination of specific $\left[{ }^{3} \mathrm{H}\right]$ saxitoxin binding. Normal rabbit serum caused no sodium channel immunoprecipitation. Hyperimmune serum produced a concentration-dependent immobilization of sodium channel to the coated Staph A (Fig. 2). Under the assay conditions employed, $20 \mu \mathrm{l}$ of hyperimmune serum precipitated $0.2 \mathrm{pmol}$ of saxitoxin binding activity. Serum previously absorbed against rat liver powder gave identical results.

Antibody staining of SDS-PAGE gels. Sarcolemmal membrane proteins were separated by SDS-PAGE (12\% acrylamide$0.075 \%$ bis) and analyzed for immunoreactivity with the SCP

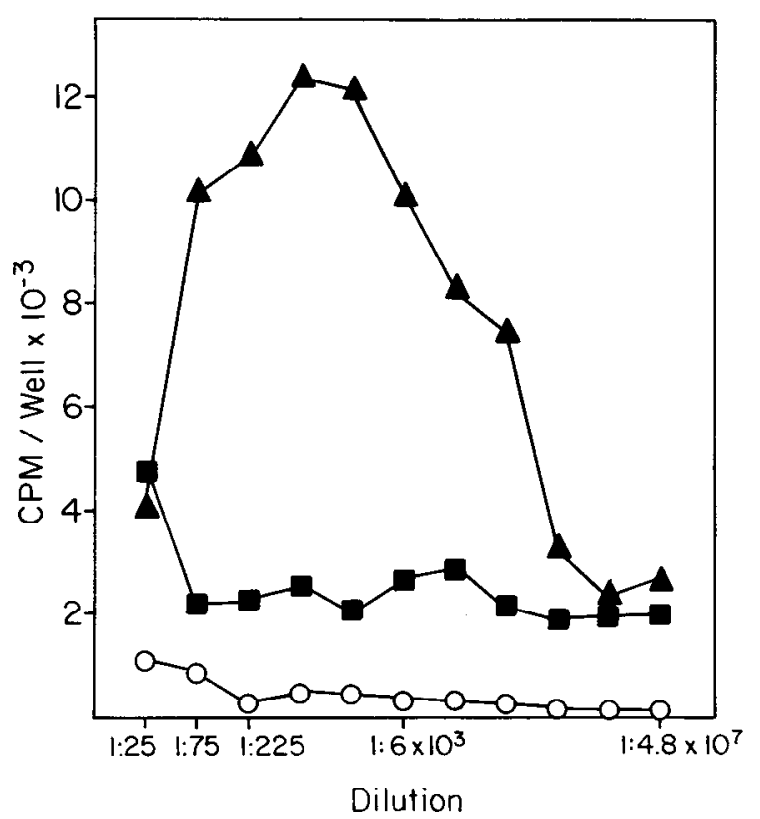

Figure 1. Solid-phase radioimmunoassay of hyperimmune serum and normal rabbit serum for anti-sodium channel activity. Antigen was presented by incubating each well with $0.03 \mu \mathrm{g}$ of purified sodium channel protein in $10 \mu \mathrm{l}$ of PBS. After washing, antigen-coated wells were exposed to varying dilutions of serum followed by [ $\left.{ }^{125} \mathrm{I}\right]$ goat antirabbit IgG. Normal rabbit serum shows no significant immunoreactivily $(O)$. Hyperimmune serum demonstrates strong reactivity to the channel protein that peaks at dilutions between $1: 100$ and $1: 1000$ in this assay and is still detectable at dilutions of $1: 10^{5}(\mathbf{\Lambda})$. The hyperimmune serum also shows a low level of binding to wells exposed only to NP-40/asolectin phosphatides (5:1 molar ratio), the detergent-phospholipid mixture used to stabilize the sodium channel during purifica-

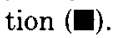

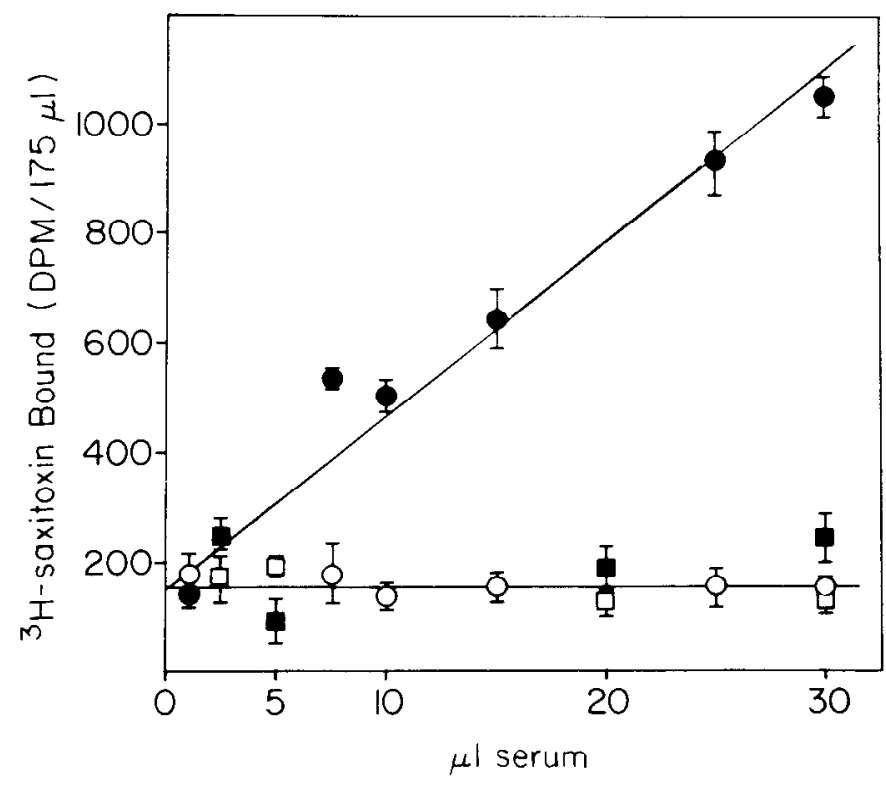

Figure 2. The SCP antiserum specifically precipitates the sodium channel from a mixture of crude solubilized sarcolemmal membrane proteins. Antibody was immobilized with Staph A, and the precipitated sodium channel was quantitated by $\left[{ }^{3} \mathrm{H}\right]$ saxitoxin binding. Increasing quantities of antiserum immobilized increasing amounts of sodium channel, as evidenced by $\left[{ }^{3} \mathrm{H}\right]$ saxitoxin binding $(\bullet)$. This represents specific ligand binding and was completely displaced to background levels by the presence of excess unlabeled toxin $(O)$. Normal rabbit serum produced no specific immunoprecipitation $\left(\mathbf{Q},\left[{ }^{3} \mathrm{H}\right]\right.$ saxitoxin; $\square$, $\left[{ }^{3} \mathrm{H}\right]$ saxitoxin $+1 \mu \mathrm{M}$ unlabeled tetrodotoxin). Error bars indicate standard deviations for values at each point.

antiserum using standard Western blotting techniques (Towbin et al., 1979). Coomassie blue stains of these gels indicated a large number of resolved bands as published previously (Barchi et al., 1980). After transfer of proteins and blocking of remaining sites with BSA, strips of the nitrocellulose image were exposed to SCP antiserum at varying dilutions and to parallel dilutions of normal rabbit serum. The bound IgG was then localized with $\left[{ }^{125} \mathrm{I}\right]$ goat anti-rabbit IgG. A diffuse band of $M_{\mathrm{r}}$ $\sim 200,000$ was labeled heavily by the SCP serum. This labeling was not seen in parallel strips exposed to normal rabbit serum (Fig. 3). This labeled band was easily detectable with dilutions of the antiserum in excess of 1:100,000 and corresponded in location to the large glycoprotein subunit of the purified sodium channel run in this gel system. Two faint smaller bands were also seen near 40,000 with the SCP antiserum but not the control. A sharp, densely stained band near the dye front was consistently seen as an artifact with both control and hyperimmune serum.

Immunoreactivity of native sarcolemmal membrane proteins. We then evaluated the SCP antiserum for reactivity against sarcolemmal membrane proteins under nondenaturing conditions. Sarcolemmal membranes were solubilized in NP-40, and solubilized proteins were separated by chromatography on Sepharose CL-6B. Protein eluted from the column as a diffuse profile consistent with the spectrum of sizes of the molecular components present. The location of the sodium channel protein in the elution profile was identified by measurement of specific saxitoxin binding in each fraction. A single peak of specific toxin binding was seen preceding the main peak of protein (Fig. 4). This peak eluted at a $K_{\text {ave }}$ consistent with that previously reported by us for the sodium channel on Sepharose $6 \mathrm{~B}$ (Barchi and Murphy, 1981) and co-migrated with the peak of purified sodium channel and toxin binding subsequently run 


\section{MW \\ Kdal}

\section{$123 \quad 456$}

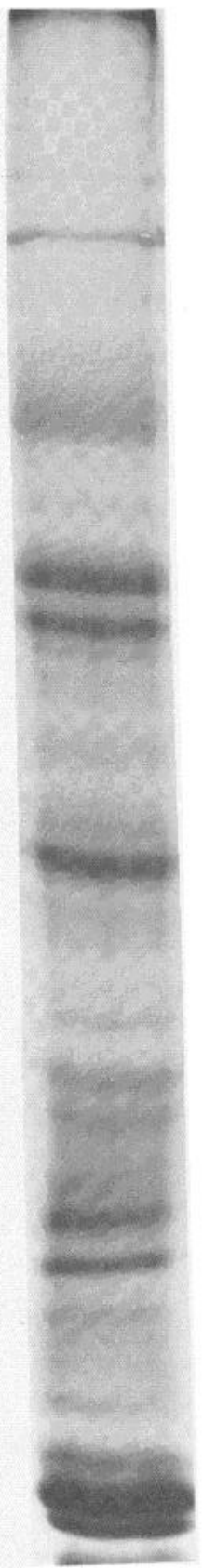

Figure 3. Staining of denatured sarcolemmal membrane proteins separated on SDS-PAGE. Isolated rat sarcolemma was solubilized in SDS $(2 \%)$ in the presence of dithioerythritol $(1.2 \%)$. After separation by SDS-PAGE, the proteins were transferred to nitrocellulose paper and exposed to SCP antiserum ( 1 to 3 ) or control (4 to 6 ) antiserum at varying dilutions. Bound antibody was then identified with [ ${ }^{125} \mathrm{I}$ ]goat anti-rabbit IgG. SCP antiserum showed prominent immunoreactivity with a diffuse band migrating at $M_{\mathrm{r}}=$ about 200,000 . This band corresponded in location to the large glycoprotein subunit of the purified sodium channel run in this gel system. A Coomassie blue stain of the separated membrane proteins prior to transfer is shown for comparison (7). Dilutions of serum used were: 1 and $4,1: 300 ; 2$ and $5,1: 3,000 ; 3$ and $6,1: 30,000$.

on the same column. Each fraction of the column was then assayed for immunoreactivity with normal rabbit serum and SCP antiserum in the solid-phase radioimmunoassay. A single included peak of immunoreactivity was seen with the antiserum that coincided with the peak of specific saxitoxin binding in the elution profile (Fig. 4). In addition, a small amount of immunoreactive material was variably present in the aggre- gated protein eluting at the column void volume. Normal rabbit serum showed no immunoreactivity to any fraction in the column profile. Antiserum previously absorbed against rat liver powder exhibited the same reactivity profile as the unabsorbed antiserum.

Immunocytochemical localization. Immunocytochemical localization of binding sites for the anti-sodium channel anti- 


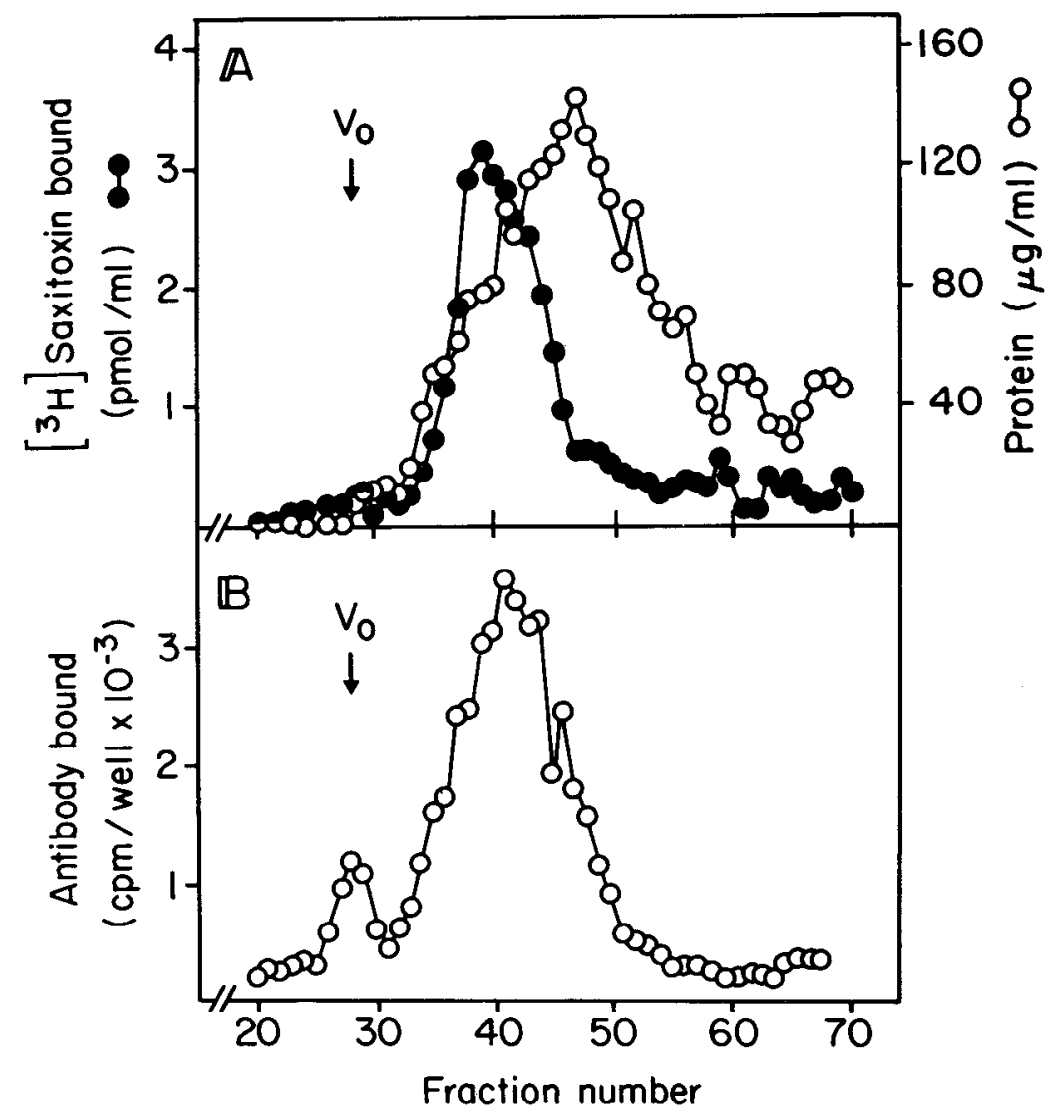

Figure 4. Immunoreactivity of SCP antiserum with nondenatured proteins in skeletal muscle sarcolemma. Surface membranes isolated from rat skeletal muscle were solubilized in NP-40, and the crude protein mixture was chromatographed on a $1 \times 95 \mathrm{~cm}$ column of Sepharose CL-6B. A, A single peak of high affinity $\left[{ }^{3} \mathrm{H}\right]$ saxitoxin binding was seen in the elution profile, identifying the location of the sodium channel $(O)$, while most of the protein eluted in later fractions (). $B$, A single peak of immunoreactivity was obtained with the volume of the column that co-eluted with the native sodium channel $(O)$. In addition, a small amount of immunoreactivity was occasionally found associated with aggregated or incompletely solubilized protein in the void volume of this column $\left(V_{o}\right)$.

serum was examined first in frozen cross-sections of rat anterior tibial or quadriceps muscle. Peroxidase-conjugated Staph A protein was used as the second reagent for visualization of the bound antibody at the light microscopic level. Control rabbit serum produced no staining under the conditions described under "Materials and Methods," although some reaction product, attributable to endogenous peroxidases, was seen in blood vessel endothelia. The SCP antiserum, either before or after absorption against rat liver powder, demonstrated dense labeling of the sarcolemmal membranes in the cross-sectioned muscle (Fig. 5). This labeling was most obvious at dilutions of the antiserum between 1:50 and 1:200, although the same pattern of staining was apparent at dilutions in excess of 1:1000. The surface membranes of muscle spindle fibers were stained to the same extent as other muscle fibers. Specific staining was not seen in connective tissue, blood vessels, or other nonmuscle elements. Rat soleus muscle, containing predominantly type II slow fibers, showed immunohistochemical staining characteristics with this antiserum indistinguishable from that seen in the predominantly fast fiber anterior tibial muscles.

Staining of the muscle surface membrane was progressively blocked by preabsorption of the antiserum with increasing amounts of highly purified sodium channel protein $(2500 \mathrm{pmol}$ of saxitoxin binding/mg of protein) (Fig. 6) but not by preincubation with much larger amounts of bovine serum albumin or with buffer containing excess NP-40/asolectin. The purified sodium channel preparation used to block labeling competitively contained only three components: a large glycoprotein and two smaller peptides of $M_{\mathrm{r}}=38,000$ and 45,000 (Barchi, 1983). No staining was seen with either normal or SCP antiserum in sections of rat liver.

Cross-reactivity of the antiserum with the sodium channel of peripheral nerve was evaluated by incubating frozen longitudinal sections of rat sciatic nerve with antiserum followed by peroxidase-conjugated protein A. Brief treatment with osmium was included to aid identification of nodal structures. The antiserum produced dense staining of the nodes of Ranvier that was absent in sections treated with control rabbit serum (Fig. 7). This staining often could be resolved as two parallel lines running longitudinally along the nodal gap at the location of the axonal membrane. No staining of the axonal membrane under the myelin was seen, even in areas where the plane of section clearly passed through the axon. Background staining produced by the osmium was identical in sections treated with either control rabbit serum or SCP antiserum. Rat cardiac muscle also showed specific reaction product along the surface membrane when frozen sections were exposed to the antiserum (Fig. 8).

We then tested SCP antiserum for cross-reactivity with skeletal muscle from other species (Table I). Strong cross- 

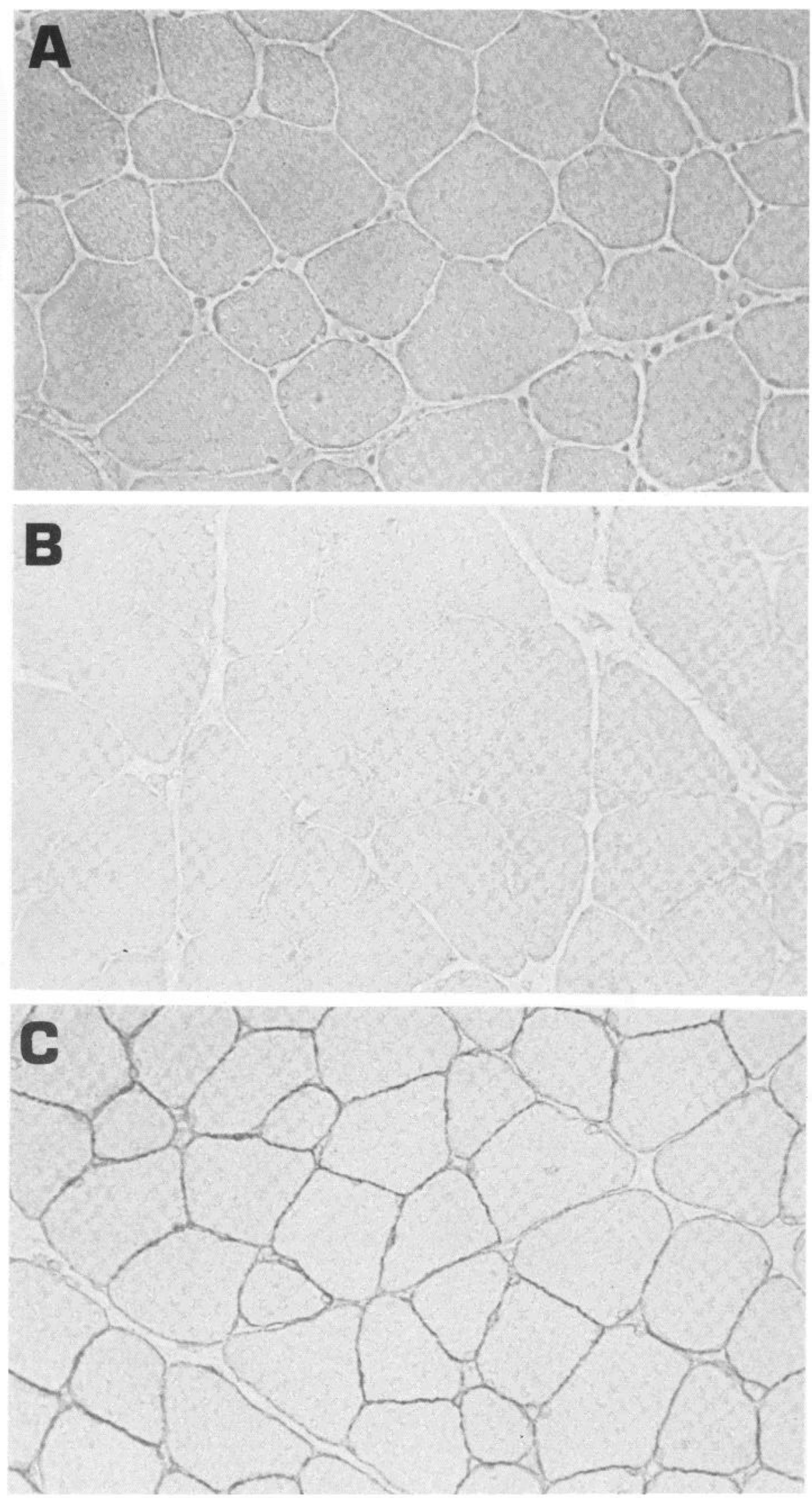

Figure 5. The SCP antiserum stained surface membranes in rat skeletal muscle. Unfixed frozen sections obtained from fresh anterior tibial muscle were exposed to SCP antiserum or control rabbit serum and bound antibody subsequently localized with peroxidase conjugated to protein A. $A$, Phase contrast of control muscles. $B$, Muscle exposed to 1:100 dilution of control rabbit serum. $C$, Muscle exposed to 1:100 dilution of SPC antiserum. All micrographs were taken at an original magnification of $\times 312$. 

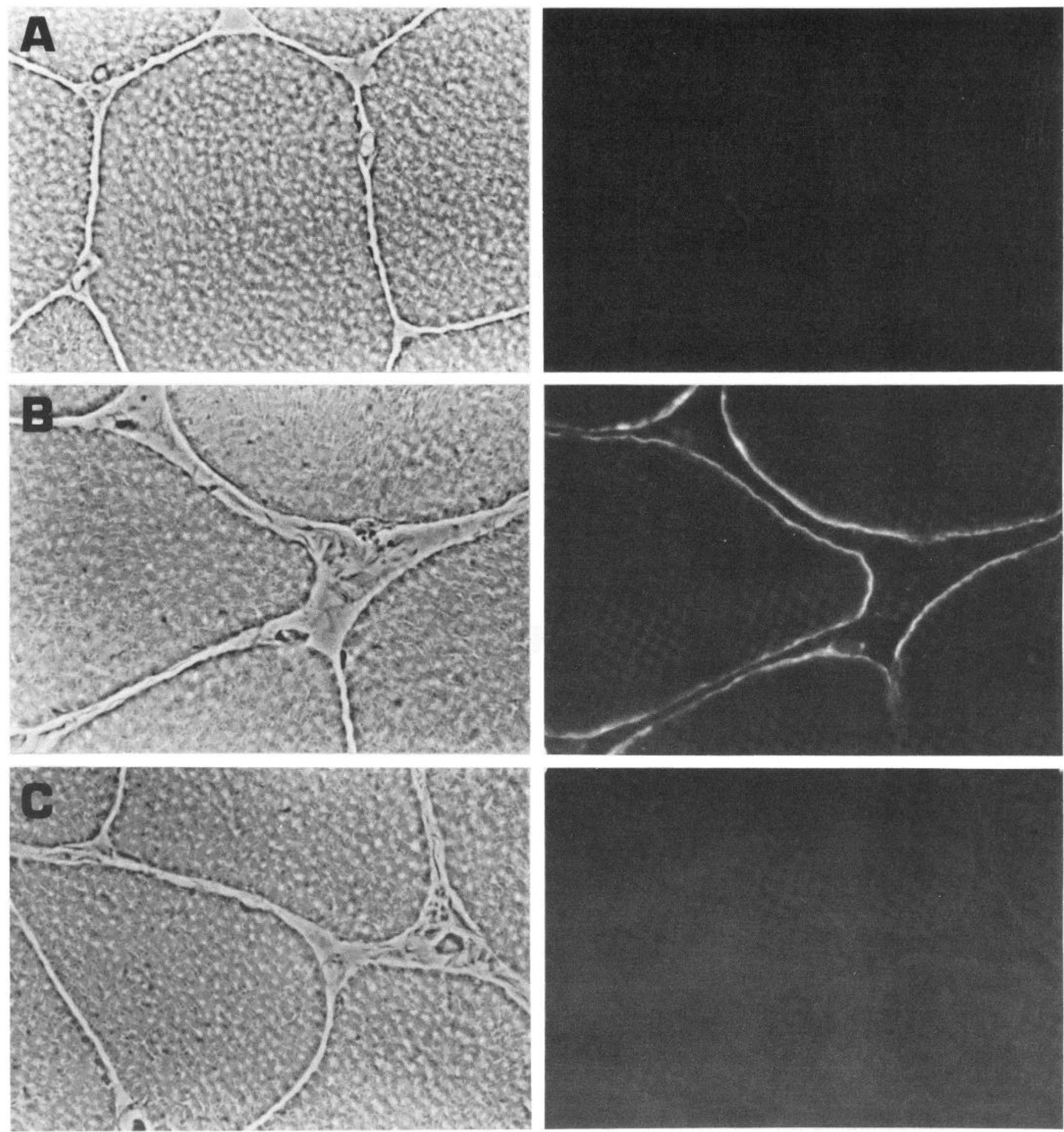

Figure 6 . The muscle surface membrane staining produced by SCP antiserum was specifically blocked with highly purified sodium channel protein. Higher dilutions of antiserum (1:750) and a more sensitive rhodamine-conjugated goat anti-rabbit second antibody were used to reduce the quantity of purified channel needed to demonstrate block. The purified protein was from the preparation documented previously (Barchi, 1983) as having a specific activity of $2500 \mathrm{pmol}$ of $\left[{ }^{3} \mathrm{H}\right]$ saxitoxin binding/mg of protein and contained only a high molecular weight glycoprotein and two smaller components of $M_{\mathrm{r}}=38,000$ and 45,000. A, Phase contrast and fluorescence micrographs of rat skeletal muscle frozen sections exposed to a 1:750 dilution of normal rabbit serum. $B$, Parallel micrographs for muscle sections stained with SCP antiserum (1:750). $C$, Muscle stained with the same dilution of SCP antiserum previously incubated with $8 \mathrm{pmol}$ of purified sodium channel/ml. All micrographs were taken at an original magnification of $\times 600$.

reactivity was observed in unfixed frozen sections of human skeletal muscle and mouse skeletal muscle. For the mouse, predominantly fast (extensor hallucis longus) and predominantly slow (soleus) muscle were examined; again both showed comparable staining. Low levels of reactivity were found in guinea pig muscle. In each case, the pattern of reactivity was identical to that described for rat muscle. No cross-reactivity was seen with chicken or rabbit muscle or with frog muscle. 


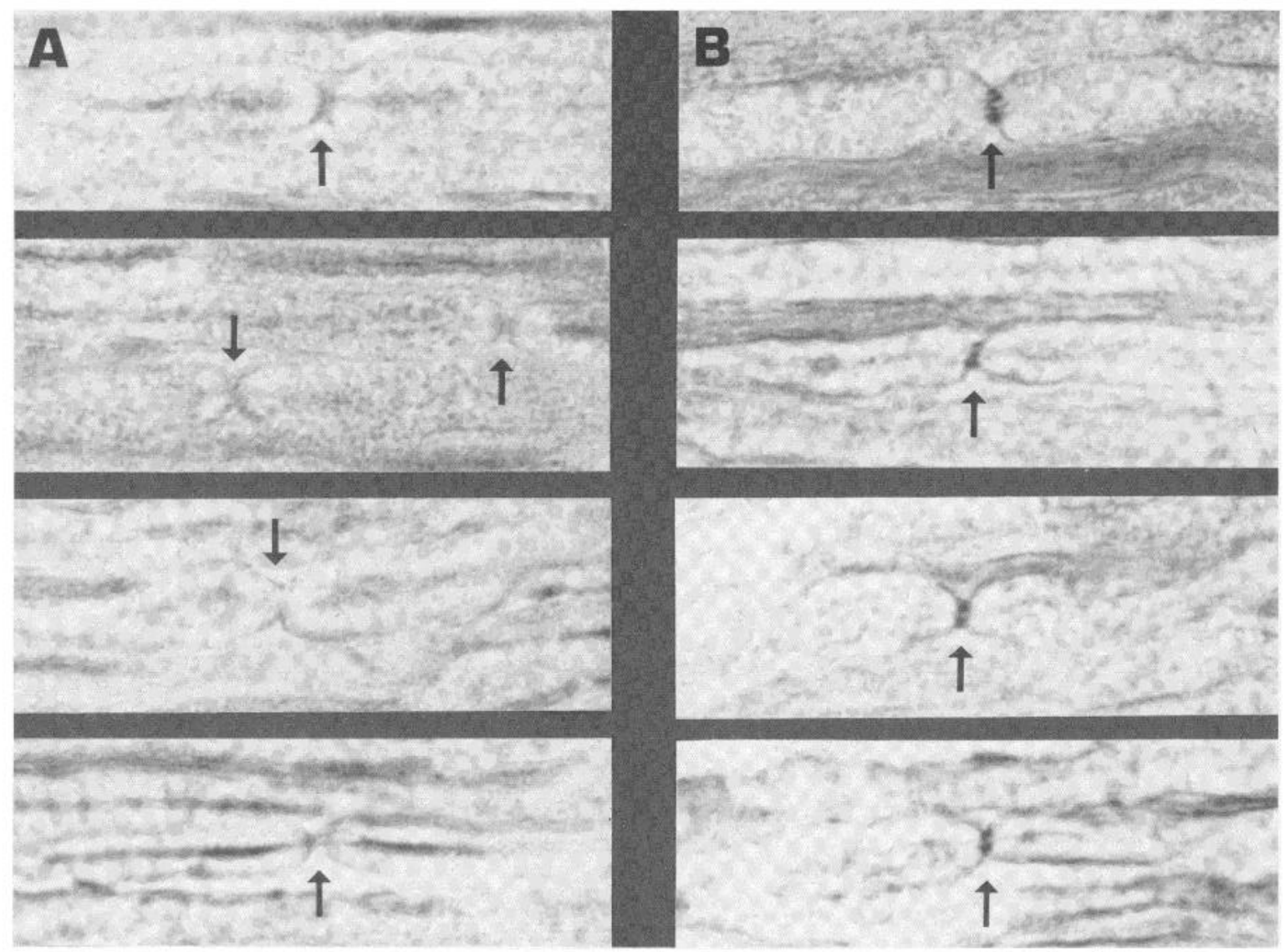

Figure 7. SCP antiserum raised against sarcolemmal sodium channels also stained nodes of Ranvier in rat peripheral nerve. Unfixed rat sciatic nerve was frozen and sectioned longitudinally. Sections were exposed to normal rabbit serum $(A)$ or SCP antiserum $(B)$ followed by peroxidaseconjugated protein A. Dense labeling of the axonal membrane at the nodes of Ranvier was seen with SCP antiserum that was absent with control serum. SCP antiserum did not appear to stain axolemma in the internode under these conditions. Arrows indicate the location of nodes in each panel.

Specific staining was seen in primary cultures of rat muscle and in L-6 cell lines as well, but not in cultured rat fibroblasts under the same conditions.

\section{Discussion}

Polyclonal antibodies raised against purified proteins have often proven useful for immunohistochemical studies, but initial documentation of their specificity must be rigorous. Although polyclonal and monoclonal antibodies to the purified sodium channel from eel electroplax have been reported (Ellisman and Levinson, 1982; Moore et al., 1982), antibodies prepared against purified mammalian sodium channel protein have not been previously described. The availability of a purified voltage-dependent sodium channel from rat skeletal muscle in our laboratory led us to attempt to prepare such an antiserum to this protein.

Specificity of the resultant polyclonal antiserum was evaluated at a number of levels. First, the SCP antiserum exhibited high titers of reactivity against purified sodium channel protein in a solid-phase radioimmunoassay. Second, the antiserum was capable of specifically immunoprecipitating the sodium channel from a preparation of crude solubilized membrane proteins in a form that retained the native saxitoxin binding properties characteristic of this channel. Third, the SCP antiserum stained predominantly a diffuse high molecular weight component of $\sim 200,000$ daltons on immunoblots of sarcolemmal membrane proteins separated by SDS-PAGE that was consistent in position and behavior with the large glycoprotein subunit of the purified sodium channel on that gel system. Finally, the antiserum reacted only with those fractions of sarcolemmal membrane proteins separated on a molecular sieving column under nondenaturing conditions that contained specific saxitoxin binding activity.

The SCP antiserum exhibited positive immunohistochemical staining against tissues known to contain the voltage-dependent sodium channel but did not react with membranes of other cell types in the same animal. Staining of these channelcontaining cells was, in turn, blocked by prior exposure of the antiserum to highly purified sodium channel protein in solution but not by other proteins or by the detergent and phospholipids present as stabilizing factors in the channel preparations. The highly purified sodium channel that blocked immunofluorescence contained only the three bands on SDS-PAGE thought to be components of the channel itself (Barchi, 1983). These considerations, along with the factors noted above, lend strong support to the contention that the SCP antiserum reacts specifically with the voltage-dependent sodium channel under the conditions employed.

Surface membrane staining showed no significant variation between fibers in rat skeletal muscle containing mixed fiber types (types I, IIa, and IIB), such as rat tibialis anterior. The soleus muscle, which contains predominantly slow fibers (type I), showed staining with the SCP antiserum indistinguishable from mixed fiber type muscles, suggesting a similarity of sodium channels in these fiber types. In addition, the positive immu- 
Figure 8 . The surface membranes of cardiac ventricular muscle fibers were also stained by the SCP antiserum. Unfixed, frozen sections of rat cardiac muscle were exposed to a 1:50 dilution of control rabbit serum $(A)$ or a comparable dilution of SCP antiserum $(B)$. Micrographs were taken at an original magnification of $\times 312$.

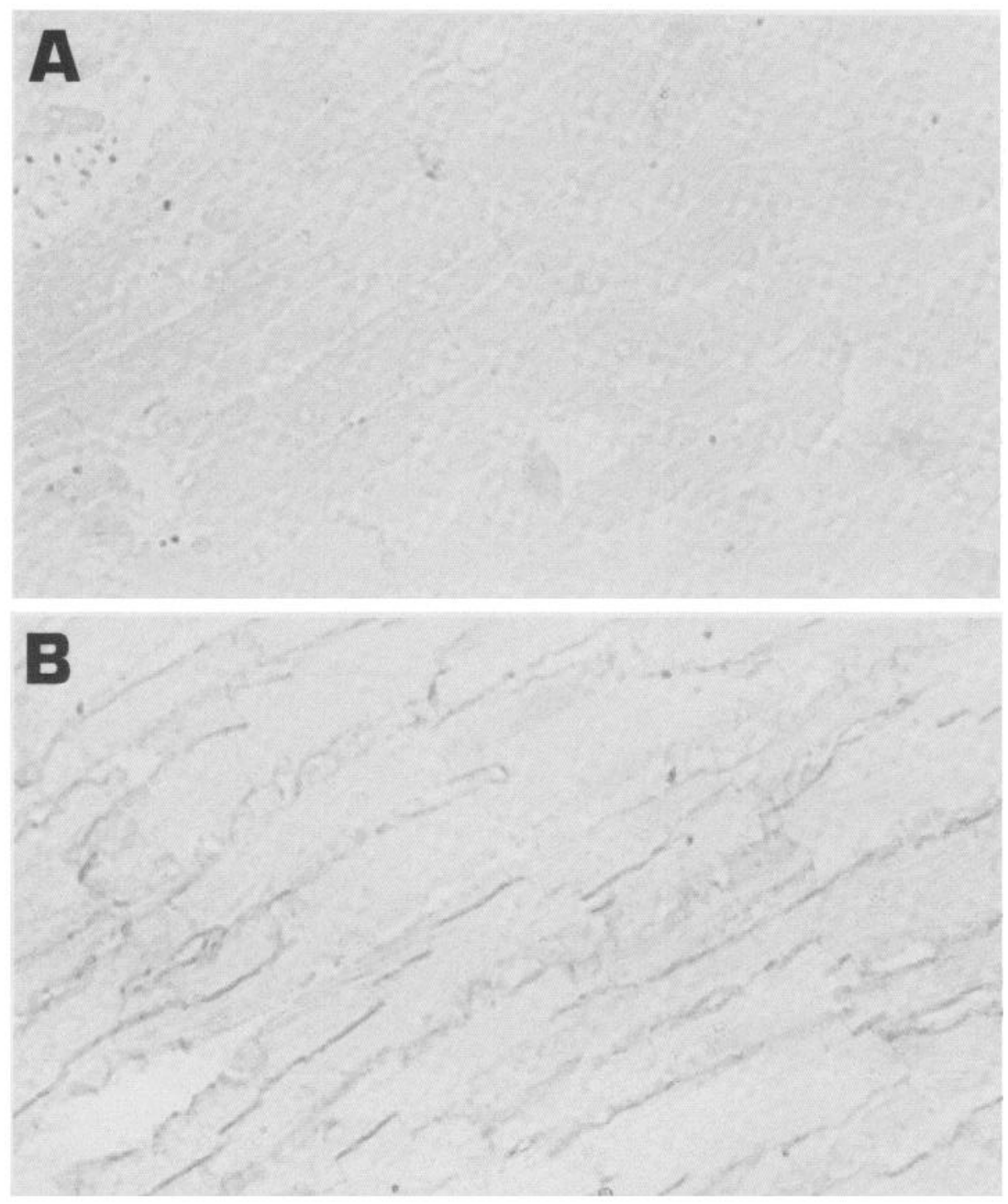

TABLE I

Immunocytochemical reactivity of SCP antiserum

\begin{tabular}{llc}
\hline \multicolumn{1}{c}{ Species } & \multicolumn{1}{c}{ Tissue } & $\begin{array}{c}\text { Immunocytochemical } \\
\text { Reactivity }\end{array}$ \\
\hline Rat & Skeletal muscle & ++++ \\
Rat & Cardiac muscle & ++ \\
Rat & Peripheral nerve & +++ (nodes only) \\
Mouse & Skeletal muscle & ++++ \\
Human & Skeletal muscle & +++ \\
Guinea pig & Skeletal muscle & + \\
Rabbit & Skeletal muscle & - \\
Chicken & Skeletal muscle & - \\
Frog & Skeletal muscle & - \\
\hline
\end{tabular}

noreactivity seen in the cardiac muscle sarcolemma indicates that the sodium channel in rat heart must also be structurally related to the skeletal muscle channel.

The SCP antiserum was raised against the voltage-dependent sodium channel of skeletal muscle yet cross-reacted with the analogous channel in peripheral nerve, suggesting a basic structural similarity between these two proteins as expressed in shared antigenic determinants. This basic similarity is supported by the close correlation seen in the physical and chemical properties of the solubilized and purified sodium channels from rat brain and rat skeletal muscle (Barchi et al., 1980; Hartshorne et al., 1980; Barchi and Murphy, 1981; Hartshorne and Catterall, 1981; Barchi, 1983). Polyclonal antibodies raised against the sodium channel of the eel electric organ, a musclederived structure, also cross-react with sodium channels in the peripheral nerve of that species (Ellisman and Levinson, 1982). The absence of detectable immunoreactive material in the axonal membrane under the myelin sheath supports the concept that the sodium channels are localized only at the nodes of Ranvier and are either not present or are present at much lower densities in the internodal regions (Ritchie and Rogart, 1977b; Ellisman and Levinson, 1982).

Antiserum raised against the rat sodium channel cross-reacts with the sarcolemmal channel of mouse and human skeletal muscle, indicating that some antigenic sites in this channel protein are shared amongst these species. The absence of crossreaction with rabbit is not surprising. Exposed antigenic sites on the sodium channel of species farther removed from rat, such as frog and chicken, may differ since cross-reactivity is not seen with these species. The polyclonal antiserum raised against adult skeletal muscle sodium channel also cross-reacts with the sodium channel of immature rat muscle in tissue culture. Thus, the immature form of the rat sodium channel 
also shares common antigenic determinants with the mature form.

The polyclonal antiserum described here appears to react specifically with the voltage-dependent sodium channel under the conditions described. It should prove useful for more detailed studies of topographical distribution of sodium channels in nerve and muscle.

\section{References}

Agnew, W., S. Levinson, J. Brabson, and M. Raftery (1978) Purification of the tetrodotoxin binding component associated with the voltagedependent sodium channel from Electrophorus electricus electroplax membranes. Proc. Natl. Acad. Sci. U. S. A. 75: 2606-2610.

Armstrong, C. (1975) Ionic pores, gates and gating current. Q. Rev. Biophys. 7: 179-210.

Barchi, R. (1983) Protein components of the purified sodium channel from rat skeletal muscle sarcolemma. J. Neurochem. 40: 1377-1385.

Barchi, R., and L. Murphy (1981) Estimate of the molecular weight of the sarcolemmal sodium channel using $\mathrm{H}_{2} \mathrm{O}-\mathrm{D}_{2} \mathrm{O}$ centrifugation. J. Neurochem. 36: 2097-2100.

Barchi, R., S. Cohen, and L. Murphy (1980) Purification from rat sarcolemma of the saxitoxin binding component of the excitable membrane sodium channel. Proc. Natl. Acad. Sci. U. S. A. 77: 13061310.

Catterall, W. (1980) Neurotoxins that act on voltage-sensitive sodium channels in excitable membranes. Annu. Rev. Pharmacol. Toxicol. 20: $15-43$.

Dubois-Dalcq, M., H. McFarland, and D. McFarlin (1977) Protein Aperoxidase. A valuable tool for the localization of antigens. J. Histochem. Cytochem. 25: 1201-1206.

Ellisman, M. H., and S. R. Levinson (1982) Immunocytochemical localization of sodium channel distributions in the excitable membranes of Electrophorus electricus. Proc. Natl. Acad. Sci. U. S. A. 79: $6707-6711$

Hartshorne, R., and W. Catterall (1981) Purification of the saxitoxin receptor of the sodium channel from rat brain. Proc. Natl Acad. Sci. U. S. A. 78: $4620-4624$.
Hartshorne, R., J. Coppersmith, and W. Catterall (1980) Size characteristics of the solubilized saxitoxin receptor of the voltage-sensitive sodium channel from rat brain. J. Biol. Chem. 255: 10572-10575.

Hodgkin, A., and A. Huxley (1952) A quantitative description of membrane current and its application to conduction and excitation in nerve. J. Physiol. (Lond.) 117: 500-544.

Kessler, S. W. (1976) Cell membrane antigen isolation with the staphylococcal protein A-antibody adsorbant. J. Immunol. 117: 1482-1490.

Laemmli, U. K. (1970) Cleavage of structural proteins during the assembly of the head of bacteriophage T4. Nature 227: 680-685.

Markwell, M., S. Haas, W. Tolbert, and L. Biever (1981) Protein determination in membrane and lipoprotein samples: Manual and automated procedures. Methods Enzymol. 72: 296-303.

Moore, H. H., L. C. Fritz, M. A. Raftery, and J. P. Brockes (1982) Isolation and characterization of a monoclonal antibody against the saxitoxin binding component from the electric organ of the eel Electrophorus electricus. Proc. Natl. Acad. Sci. U. S. A. 79: 16731677.

Ritchie, J. M., and R. Rogart (1977a) The binding of saxitoxin and tetrodotoxin to excitable tissues. Rev. Physiol. Biochem. Pharmacol. 79: 250.

Ritchie, J. M., and R. B. Rogart (1977b) The density of sodium channels in mammalian myelinated nerve fibers and the nature of the axonal membrane under the myelin sheath. Proc. Natl. Acad. Sci. U. S. A. 74: $211-215$

Towbin, H., T. Staehelin, and J. Gordon (1979) Electrophoretic transfer of proteins from polyacrylamide gels to nitrocellulose sheets: Procedure and some application. Proc. Natl. Acad. Sci. U. S. A. 76: 4350-4354.

Weigele, J., and R. Barchi (1978) Analysis of saxitoxin binding in isolated synaptosomes using a rapid filtration assay. FEBS Lett. 91: 310-314.

Weir, E. E., T. G. Pretlow, H. Pitts, and E. E. Williams (1974) A more sensitive and specific histochemical peroxidase stain for the localization of cellular antigen by the enzyme antibody conjugated method. J. Histochem. Cytochem. 22: 1135-1140. 